\title{
Government bonds and the cross-section of stock returns*
}

\author{
Malcolm Baker \\ Harvard Business School and NBER \\ mbaker@hbs.edu \\ Jeffrey Wurgler \\ NYU Stern School of Business and NBER \\ jwurgler@stern.nyu.edu
}

January 5, 2006

\begin{abstract}
We document that U.S. government bonds comove more strongly with "bond-like stocks"stocks of large, mature, low-volatility, profitable, dividend-paying firms that are neither high growth nor distressed. This pattern may be caused by common shocks to real cash flows, rationally required returns, or flights to quality in which drops in investor sentiment increase the demand for both government bonds and bond-like stocks. Consistent with both the required returns and sentiment channels, we find a common predictable component in bonds and bondlike stocks. Consistent with the sentiment channel, we find that bonds and bond-like stocks comove with inflows into government bond and conservative stock mutual funds.
\end{abstract}

\footnotetext{
* For helpful comments, we thank Pascal Maenhoet, Stefan Nagel, Stijn Van Nieuwerburgh, Geoff Verter, and Pierre-Olivier Weill, and participants at Stanford FRILLs and Barclays Global Investors. We thank the Investment Company Institute for data on mutual fund flows. Baker gratefully acknowledges financial support from the Division of Research of the Harvard Business School.
} 


\section{Introduction}

In this paper, our main goal is to characterize empirically the relationship between the returns on U.S. government bonds and different regions of the cross-section of stocks. The study is motivated by the fact that almost all prior research on the relationship between bond and stock returns has focused on broad stock indexes. ${ }^{1}$ Yet there are essentially three non-exclusive reasons that one would expect important cross-sectional differences in this relationship:

- Common shocks to real cash flows. Nominal cash flows on government bonds are fixed, but real cash flows are not. In efficient markets, bonds and stocks can move together because expected real cash flows move together. Cross-stock differences can easily emerge. For example, a business cycle contraction may be associated with lower inflation and rising bond prices. A contraction may also have less of an impact on real cash flows among stable, mature firms than more speculative growth firms or already-distressed firms. Hence stable, mature, "bond-like” firms might be expected to comove relatively more strongly with bonds.

- Common shocks to rationally required returns. The other reason why asset prices move together in efficient markets is that they experience common shocks to rationally required returns, i.e. discount rates. If certain stocks' rationally required returns are closer to those on government bonds, then shocks to required returns can induce cross-stock differences in the correlation between stocks and bonds. For example, an increase in aggregate risk

\footnotetext{
${ }^{1}$ For example, see Fama and French (1989), Shiller and Beltratti (1992), Campbell and Ammer (1993), Gulko (2002), Chordia, Sarkar, and Subrahmanyam (2003), and Connolly, Stivers, and Sun (2005), which are described more fully in Section II.
} 
aversion increases the market risk premium and may lead to a better performance of longterm bonds and stable, mature firms than more speculative firms. Similarly, holding the risk premium constant, the betas of government bonds and stable, mature firms may be more closely linked over time than the betas of more speculative firms.

- Investor sentiment and flights to quality. Common mispricings driven by broad shifts in investor sentiment provide a third channel. Baker and Wurgler (2005) find that stocks that are hard to value and hard to arbitrage, such as speculative growth firms and distressed firms, tend to be overpriced relative to other stocks when an index of sentiment takes high values. Likewise, such stocks are underpriced relative to other stocks when sentiment is low. The idea extends naturally to include bonds: High sentiment is likely to be associated with high investor demand for speculative stocks relative to investor demand for stable, mature firms and government bonds. Under this story, "flights to quality,” such as those alleged in August 1998 and around other crashes and crises, are simply dips in sentiment in which investors shift money toward what appear to be safe assets without a sophisticated eye to expected risks and returns.

We start by documenting the basic return comovement patterns between government bonds and the cross-section of stocks. Our main finding is that government bonds comove much more strongly with "bond-like" stocks. That is, large stocks, long-listed stocks, stocks of profitable and dividend-paying firms, and stocks of firms with mediocre growth opportunities are more positively correlated with government bonds, controlling for overall stock market returns. Smaller, newly-listed firms, and firms with extremely strong growth opportunities or those in 
distress, display a considerably less positive correlation to bonds, controlling for overall stock market returns.

Our secondary goal in this paper is to shed some light on the causes of these patterns. They may reflect any or all of the mechanisms above; a complete and unambiguous attribution is beyond our ability, but good progress is possible. We start by showing that there are closely overlapping predictability patterns in bonds and bond-like stocks. The same yield curve variables that predict returns on bonds, such as the term spread (Fama and French (1989) and Campbell and Shiller (1991)) and combinations of forward rates (Cochrane and Piazzesi (2005)), also predict the returns of "bond-like" stocks relative to more speculative stocks. We also find new predictability relationships running from stocks to bonds. Namely, the sentiment index that Baker and Wurgler (2005) use to predict the future relative returns on bond-like stocks is also useful for predicting bond returns.

Such predictability patterns narrow down the potential explanations for the main results. While not in any way ruling out a channel based on common shocks to real cash flows, they indicate that an important component of the correlation patterns can be traced to one or both of the remaining stories: either investor sentiment is causing predictable corrections in prices of stocks and bonds, or time-varying, rationally required returns is inducing predictability. That is, common shocks to real cash flows cannot be a complete explanation.

Distinguishing further between these two stories is challenging, since both classical asset pricing models and sentiment-based stories are quite flexible. Time-varying rationally required returns require either time-varying betas or market risk premia. We test for time-varying market betas directly and find a change in the right direction. That is, the betas of speculative stocks rise when bond returns are predicted to be low (and the returns on speculative stocks are predicted to 
be relatively high). However, simple calibrations suggest that market betas do not change by nearly enough to generate the observed predictability patterns with a constant market risk premium. The other possibility is a time-varying market risk premium. But, variation in the market risk premium is unable to explain our findings: Higher beta (or smaller, high-volatility, nonpaying, unprofitable) firms are frequently predicted to have lower returns than lower-risk regions of the cross-section of stocks. Thus, common shocks to required returns also fail to provide a complete explanation.

By process of elimination, this logic supports the existence of a sentiment, or flight to quality, channel. Reassuringly, though, there is also affirmative evidence for this channel. We study mutual fund flows, which measure the demands of a subset of investors especially likely to be prone to sentiment: retail investors. We find that mutual fund flows display a similar pattern. Flows into government bond funds or conservative stock funds (e.g. balanced or income equity funds) and away from speculative stock funds (e.g. growth or aggressive growth funds) have a similar pattern of comovement with the cross-section of stock returns. We use factor analysis to identify the conservative component of mutual fund flows. Like bond returns, these flows are more positively correlated with the returns of large stocks, long-listed stocks, stocks of profitable and dividend-paying firms, and stocks of firms with mediocre growth opportunities.

In summary, we find that there are important cross-sectional differences in the correlation between government bonds and stocks, and that sentiment appears to be an important part of the explanation of this pattern. Clearly, however, we do not rule out that common shocks to timevarying rationally required returns and real cash flows are also significant.

The paper proceeds as follows. Section II briefly reviews related literature. Section III describes the data and the basic empirical relationships between government bonds and the 
cross-section of stocks. Section IV discusses overlapping predictability patterns. Section V discusses interpretations based on required returns and sentiment. Section VI concludes.

\section{Related literature}

The prior literature that considers stocks and government bonds in the same study typically focuses on stock market indexes. Fama and Schwert (1977), Keim and Stambaugh (1986), and Campbell (1987) were early contributions in a large subsequent literature that used dividend yields and interest rates to forecast stock and bond index returns. For example, using the term spread, the default spread, and the dividend yield, Fama and French (1989) find common predictable components in bond indexes and equal- and value-weighted stock indexes. Shiller and Beltratti (1992) and Campbell and Ammer (1993) use present-value relations in an effort to decompose stock and bond index returns into shocks related of real cash flows and discount rates.

One exception to the focus on stock market indexes is Fama and French (1993). Among their many findings, Fama and French report that the term spread and the default spread have strong contemporaneous relationships to several size- and book-to-market-based stock portfolios. However, they do not attempt to develop or interpret the cross-sectional differences in the relationships, as their main focus in this part of their study is simply to establish that there is a positive covariance between yield-curve variables and a broad range of stock portfolios.

Another notable omission in the prior literature that we address is the frequent failure to directly treat the possibility of shifting sentiment or flights to quality. Despite frequent allusions in the financial media to drops in sentiment and demand shifts from speculative stocks to safer 
stocks and bonds, there has been little direct consideration of this idea in the research literature. ${ }^{2}$ An interesting recent exception is Connolly, Stivers, and Sun (2005), who find that government bond returns tend to be high, relative to stock index returns, on days when the implied volatility of equity index options increases. Relatedly, Gulko (2002) finds that the typically positive correlation between stocks and bonds becomes negative in months of stock market crashes. And Baker and Wurgler (2005) find that investor sentiment has larger effects on speculative stocks than more bond-like stocks, consistent with flights to quality (and, sometimes, drifts away from quality) within the stock market, but no aspect of their study involves the bond market.

\section{Government bonds and the cross-section of stocks: Basic relationships}

To characterize how the cross-section of stock returns covaries with bond returns, we study a broad range of stock portfolios, including portfolios based on firm size, firm age (period since listing), profitability, dividend policy, and growth opportunities and/or distress. We first describe the data and then the basic regression results.

\section{A. Data}

The stock portfolio constructions follow Fama and French (1992) and Baker and Wurgler (2005). The firm-level data is from the merged CRSP-Compustat database. The sample includes all common stock (share codes 10 and 11) between 1962 through 2001. Accounting data for fiscal year-ends in calendar year $t-1$ are matched to monthly returns from July $t$ through June $t+1$.

\footnotetext{
${ }^{2}$ The financial press often refers to August 1998, when Russia devalued its currency and defaulted on some debt, leading to the collapse of Long-Term Capital Management, in terms of a "flight to quality." Investors are said to have fled to safer markets and to safer securities within markets. Similar allegations occurred in October 1987, which included the largest one-day crash in U.S. history. "When investors are scared, they look for safety. They adjust their portfolios to include more safe assets and fewer risky assets. ... This kind of movement is usually referred to as a 'flight to quality.' Government bond prices go up, stock prices fall.” Chicago Federal Reserve Bank News Letter, December 1987, as cited by Barsky (1989). Or, "When stocks are expected to show weakness, investment funds often flow to the perceived haven of the bond market, with that shift usually going into reverse when, as yesterday, equities start to strengthen.” John Parry, The Wall Street Journal, August 1, 2001, page C1, as cited by Chordia, Sarkar, and Subrahmanyam (2003).
} 
Table 1 shows average monthly returns and standard deviations for the stock portfolios. Size and age characteristics include market equity $M E$ from June of year $t$, measured as price times shares outstanding from CRSP. ME is matched to monthly returns from July of year $t$ through June of year $t+1$. Age is the number of years since the firm's first appearance on CRSP, measured to the nearest month. Return volatility, denoted by $\sigma$, is the standard deviation of (raw) monthly returns over the twelve months ending in June of year $t$. If there are at least nine returns to estimate it, $\sigma$ is matched to monthly returns from July of year $t$ through June of year $t^{+}+1$. Of the three, size exhibits the most unconditional predictive power.

Profitability is measured by the return on equity $E / B E$. Earnings $(E)$ is income before extraordinary items (Item 18) plus income statement deferred taxes (Item 50) minus preferred dividends (Item 19), if earnings are positive; book equity $(B E)$ is shareholders equity (Item 60) plus balance sheet deferred taxes (Item 35). Dividend policy is measured by dividends to equity $D / B E$, which is dividends per share at the ex date (Item 26) times Compustat shares outstanding (Item 25) divided by book equity. For dividends and profitability, there is a salient distinction at zero, so we split dividend payers and profitable firms into deciles and study nonpayers and unprofitable firms separately. Neither profitability nor dividends displays a large unconditional effect in average returns.

Characteristics indicating growth opportunities, distress, or both include book-to-market equity $B E / M E$, whose elements are defined above. External finance $E F / A$ is the change in assets (Item 6) minus the change in retained earnings (Item 36) divided by assets. Sales growth (GS) is the change in net sales (Item 12) divided by prior-year net sales. Table 1 shows that each of these three variables displays some unconditional predictive power, as in prior work. 
Most of these characteristics are simple to interpret, but the growth and distress variables require extra attention. With book-to-market, high values may indicate distress and low values may indicate high growth opportunities. In addition, as a scaled-price variable, book-to-market is a generic valuation indicator, varying with any source of mispricing or rational expected returns. Likewise, low values of sales growth and external finance (which are negative numbers) may indicate distress, while high values may reflect high growth opportunities. And to the extent that external finance is driven by investor demand and/or market timing, $E F / A$ is also a generic misvaluation indicator.

Table 2 summarizes bond yields and returns data. In the top panel, the risk-free rate $r_{f}$ is the yield on Treasury bills, and the term spread is the difference between the long-term Treasury bond yield and the Treasury bill yield. These yields are from Ibbotson Associates (2005). The credit spread is the difference between the commercial paper yield and the Treasury bill yield. The commercial paper yield series, available on the NBER website, is based on data collected by the Federal Reserve Board. The credit term spread is the difference between Moody's Aaa bond yields, also as reported by the Federal Reserve Board, and the commercial paper yield. Fama and Bliss (1987) and Cochrane and Piazzesi (2004) use forward rates to predict bond returns. We use the one- to five-year forward rates derived from the Fama-Bliss zero coupon yield curve from CRSP. The table reports twelve-month moving averages of forward rates.

The bottom panel of Table 2 summarizes government bond excess returns. Monthly excess returns on intermediate-term government bonds $r_{I T}-r_{f}$ and long-term government bonds $r_{L T}-r_{f}$ are both constructed using data from Ibbotson Associates (2005). 


\section{B. Basic relationships}

Table 3 reports the main results of the paper. We regress monthly excess stock portfolio returns on contemporaneous excess stock market returns and excess long-term bond returns:

$$
r_{p t}-r_{f t}=a_{p}+\beta_{p}\left(r_{m t}-r_{f t}\right)+b_{p}\left(r_{b t}-r_{f t}\right)+u_{p t} .
$$

Monthly stock market returns are from the NYSE/Amex/Nasdaq CRSP value-weighted series. We are interested in the coefficient $b_{p}$, which tells us the relationship between stock portfolio $p$ and bonds that arises over and above their relationship through general stock market returns. In this way, we document cross-sectional differences in the relationship between stocks and bonds.

Table 3 reveals a striking but intuitive pattern. Stock portfolios that can be characterized as "speculative” have a lower partial correlation with bond returns: Small-capitalization stocks, young stocks, high-volatility stocks, non-dividend paying stocks, and unprofitable stocks all display significant negative coefficients $b_{p}$. The minimum coefficient of -0.47 is on unprofitable stocks. Hence a one percentage point higher excess return on long-term bonds is associated with a 0.47 percentage point lower excess return on low-volatility stocks, controlling for general stock market returns.

The bottom three rows in Table 3 show that there is a U-shaped pattern in the coefficients on the growth and distress variables — both high growth and distressed firms tend to have a lower correlation with bonds. Stable and mature firms in the middle deciles, on the other hand, show less of an unusual relationship to bonds. These U-shaped patterns mirror those studied in Baker and Wurgler (2005). They find that high growth and distressed stocks are more sensitive to investor sentiment measures than firms in the middle deciles.

In contrast, stock portfolios that contain less speculative stocks (or, more succinctly, "bond-like" stocks) show a considerably higher partial correlation with bond returns. For 
instance, large stocks, low-volatility stocks, and high-dividend stocks show a significantly positive partial correlation with bond returns. The maximum coefficient is 0.17 on the lowestvolatility decile of stocks, indicating that a one percentage point higher excess return on longterm bonds is associated with a 0.17 percentage point higher monthly excess return on lowvolatility stocks, controlling for general stock market returns.

The left panels of Figure 1 plot the coefficients across stock deciles $b_{p}$, as reported in Table 3. The middle panels plot the coefficients $b_{p}$ that are estimated after adding Fama and French's (1993) factors $S M B$ and $H M L$ and the momentum factor $U M D$ to Eq. (1). The patterns in the coefficient estimates are qualitatively similar, but not surprisingly they are dampened by the inclusion of the additional stock portfolios. For example, comparing Panels A and D, the effect of bond returns on high-volatility stocks goes from -0.45 without the additional controls to -0.21 with them, and the coefficient for low-volatility stocks stays at 0.17 .

Finally, since several of the characteristics we examine are correlated with firm size, we perform a robustness check to determine whether the pattern of coefficients holds after explicit controls for firm size. The right panels of Figure 1 use a double sort methodology in which we perform separate regressions within each size quintile and then report the average coefficient across the five quintiles. The pattern of results that we obtain is quite similar to those from simpler methodologies, indicating that the pattern of results is not simply driven by size.

Overall, these results significantly develop those in Fama and French (1993). They stress the point that a broad variety of stock portfolios are correlated with bonds; we have shown that there are large cross-sectional differences in this correlation. 


\section{Overlapping predictability in bonds and bond-like stocks}

Having established the stylized facts, we now shift our investigation to a brief study of their causes. As mentioned in the Introduction, the possibilities include common shocks to real cash flows, common shocks to rationally required returns, and investor sentiment. A full and convincing attribution is an unrealistic goal, however, since there is no accepted model of rationally required returns.

Our prior is that common shocks to real cash flows are relatively likely to be part of the explanation. The importance of the other two stories is less clear. Thus, a particularly interesting question is whether those stories can be shown to play any significant role. We pursue this question in this section. We find that there is a common component in the predicted returns on bonds and bond-like stocks. This is consistent with both the rationally required returns and the sentiment mechanisms, but not the real cash flows mechanism.

\section{A. $\quad$ Predictability in bond returns extends to bond-like stocks}

There is an acknowledged failure of the simple version of the expectations hypothesis, which holds that excess bond returns are not predictable. Fama and French (1989) and Campbell and Shiller (1991), among others, find that the excess returns on long-term bonds are somewhat predictable based on such variables as the term spread. Cochrane and Piazzesi (2005) find another useful predictor based on a tent-shaped function of one- to five-year forward rates. As usual, predictability may reflect time variation in rationally required returns or the correction of sentiment-driven mispricing. Either way, the results raise an interesting question for us, namely whether the predictable variation extends to the cross-section of stocks.

We start by replicating prior bond predictability results. Table 4 reports the results of regressions to predict monthly excess returns on intermediate- and long-term government bonds. 
In the left columns, we augment standard Campbell-Shiller regressions by including the T-bill yield and the term spread as well as the credit spread and the credit term spread. All these yields are lagged six months in the predictive regressions. In the middle columns, we report regressions used to construct the Cochrane-Piazzesi forecasting factor, verifying that a tent-shaped function of one- to five-year forward rates emerges as a useful combination. In the right columns, we use the forecasting factor reported in Cochrane and Piazzesi (2005). ${ }^{3}$ The results are similar to those reported by earlier work.

Next, we take these forecasts and ask whether the predictable variation in bonds extends to bond-like stocks. We regress stock portfolio returns on contemporaneous excess stock market returns and the predicted excess bond return:

$$
r_{p t}-r_{f t}=a_{p}+\beta_{p}\left(r_{m t}-r_{f t}\right)+t_{p}\left(r_{b t}-r_{f t}\right)^{*}+u_{p t}
$$

In Table 5, we report the coefficient $t_{p}$ in regressions where $\left(r_{b t}-r_{f t}\right)^{*}$ is based on the CampbellShiller model. In Table 6, the predictions are based on the Cochrane-Piazzesi model.

The results show that predictable variation in bond returns does indeed extend to certain regions of the cross-section of stocks. When excess bond returns are predicted to be high, the returns on the stocks of large, established, low-volatility firms are also significantly higher than usual, and small, young, nonpaying, unprofitable, high-volatility, and high-growth and distressed firms are predicted to have significantly lower stock returns than usual. Interestingly, the $t_{p}$ coefficient estimates from Eq. (2) are similar in sign but generally somewhat larger in magnitude than the $b_{p}$ coefficients estimated from Eq. (1). Thus, stock returns are especially sensitive to the predictable component of bond returns.

\footnotetext{
${ }^{3}$ We are interested in forecasting monthly returns. Cochrane and Piazzesi (2005) use their factor to forecast overlapping annual returns from month $t+1$ through month $t+12$. To be consistent with the spirit of their predictor, we use a 12-month moving average of their factor as a predictor of monthly returns.
} 
Figure 2 shows these results graphically. The left panels plot the coefficients across stock deciles $t_{p}$ from Table 5 . The middle panels plot the coefficients that are estimated after adding $S M B, H M L$, and $U M D$ to Eq. (2). The right panels plot the coefficients from double sorts that explicitly control for firm size, as described earlier. There is a clear relationship between the cross-sectional patterns in Figure 2 and those in Figure 1.

\section{B. $\quad$ Predictability in bond-like stocks extends to bonds}

Baker and Wurgler (2005) find that the relative returns on hard to value and hard to arbitrage stocks can be forecast (in sample) using a simple index of investor sentiment. In particular, stock returns on small, newly listed, low return volatility, non-dividend paying, unprofitable, high growth or distressed firms are low, relative to more "bond-like" stocks, when beginning-of-period sentiment is high. Likewise, when beginning-of-period sentiment is low, more speculative stocks subsequently enjoy higher returns than bond-like stocks. The authors interpret this evidence as the correction of sentiment-based mispricings which are more severe in speculative stocks than bond-like stocks.

Their results are consistent with a "flight-to-quality" dynamic within the stock market, while the financial press often suggests flights to quality across international markets, from U.S. stocks to U.S. bonds, from corporate bonds into Treasuries, from junk bonds to investment grade bonds, and so on. Of course, both effects could reflect the same shift in sentiment, with a negative shock causing a flight to all types of "safe" securities. If so, investor sentiment might occasionally be strong enough to affect bond prices to the point where it gives rise to predictable variation in bond returns.

Baker and Wurgler (2005)'s sentiment index is based on the first principal component of six underlying proxies that prior work has argued to contain at least some element of investor 
sentiment. ${ }^{4}$ To isolate the common sentiment component from common macroeconomic-driven components in these proxies, their procedure is to first orthogonalize each of the six sentiment proxies to several macroeconomic aggregates, including industrial production, the NBER recession indicator, and growth in consumption. They call the resulting index $S E N T I M E N T^{\perp}$, and show that it visibly lines up with historical accounts of stock market bubbles and crashes.

To test whether sentiment-related variation identified from stock market data spills over to bonds, we examine whether SENTIMENT ${ }^{\perp}$ has forecasting power for excess bond returns. We run forecasting regressions that use only $S E N T I M E N T^{\perp}$ as well as multivariate regressions that include the predicted value from standard yield curve-based bond return forecasters:

$$
r_{b t}-r_{f t}=a+\beta\left(r_{m t}-r_{f t}\right)+b\left(r_{b t}-r_{f t}\right)^{*}+\operatorname{SSENTIMENT~} T_{t-1}^{\perp}+u_{t} .
$$

Note that Eq. (3) controls for contemporaneous stock market returns to ensure that any predictive power of the sentiment proxy or the usual yield-curve forecasters are not coming from their ability to forecast the stock market. Including both forecasters also sheds light on whether any predictive power of the sentiment measure closely overlaps with, or is largely independent of, the predictive power of yield curve variables. The predicted value of excess bond returns is based on the results from Table 4: the augmented Campbell-Shiller forecasts use 6-month lagged yield curve variables, while the Cochrane-Piazzesi forecasts use a factor based on the twelve-month moving average of forward rates. SENTIMENT ${ }^{\perp}$ is measured annually, so we use the end-ofDecember value to forecast returns over the next twelve months.

\footnotetext{
${ }^{4}$ These proxies include the closed-end fund discount, the number of IPOs, average first-day returns on IPOs, the dividend premium (the log difference between the value-weighted average market-to-book ratio of dividend payers and nonpayers), the equity share in new issues (aggregate equity issuance as a fraction of total aggregate equity and debt issuance), and detrended NYSE turnover (the log of the deviation from a 5-year moving average). See their paper for the motivation of these proxies, their correlations, and further details on the construction of the index.
} 
Table 7 shows the results. Specifications that exclude the yield curve-based predictors show that the investor sentiment measure has significant power to predict excess bond returns. In particular, a one-standard-deviation higher value of $S E N T I M E N T^{\perp}$ from its historical mean is associated with 0.39 percent per month higher excess returns on long-term bonds and 0.23 percent per month higher excess returns on intermediate-term bonds.

The inclusion of the yield curve-based predictors reduces the effect of SENTIMENT ${ }^{\perp}$. In some specifications it retains marginal significance, in others it does not. Thus, the variation in SENTIMENT ${ }^{\perp}$ that predicts bond returns overlaps with the variation in yield curve-based predictors. Figure 3 shows why. The correlation of the Campbell-Shiller and Cochrane-Piazzesi predictions is 0.53 ; the correlation of the Campbell-Shiller prediction and SENTIMENT ${ }^{\perp}$ is 0.23 ; and the correlation of the Cochrane-Piazzesi prediction and SENTIMENT ${ }^{\perp}$ is 0.16 . While all of these are highly significant, the yield curve-based predictions clearly overlap with each other more closely than they do with $S E N T I M E N T^{\perp}$. Finally, recall that bond return volatility increased in the late-1970s through mid-1980s, and so forecasting success for the full sample depends importantly on success over this period. Interestingly, Figure 3 suggests that the yield curvebased predictors and $S E N T I M E N T^{\perp}$ are especially linked in this period.

\section{Investor sentiment as a partial explanation}

The overlapping return predictability confirms that at least some of the basic correlation patterns must be due to either time-varying, rationally required returns or periodic sentimentinduced mispricings. In this section we examine which of these stories is more plausible. We first discuss several aspects of the rationally required returns explanation. Finding a less than 
complete explanation, we turn to a test based on mutual fund flows which provides some positive evidence for a sentiment channel.

\section{A. Determinants of rationally required returns}

The time-varying, rationally required returns story argues that either risk factor loadings - betas - are changing over time or risk premia are changing. We test the first possibility directly, by asking whether betas on bonds and bond-like stocks increase as SENTIMENT ${ }^{\perp}$ or fitted bond returns increase. In principle, this could induce the cross-market predictability patterns observed in the previous section.

Baker and Wurgler (2005) have conduct this exercise in some cases of interest here. They run regressions on long-short stock portfolios of the form:

$$
r_{p_{i t}=\text { High }, t}-r_{p_{i t}=\text { Low }, t}=c+d \operatorname{SENTIMENT} T_{t-1}^{\perp}+\beta\left(e+f \operatorname{SENTIMENT} T_{t-1}^{\perp}\right)\left(r_{m t}-r_{f t}\right)+u_{p t} .
$$

The time-varying betas interpretation of why SENTIMENT ${ }^{\perp}$ predicts the relative returns on bondlike stocks (and bonds) requires that the composite coefficient $\beta f$ be higher for bond-like stocks. Baker and Wurgler find that the sign of $\beta f$ only rarely lines up with the sign of the return predictability. The composite coefficients are small and in the wrong direction in the majority of portfolios. Replacing stock market returns with consumption growth gives the same conclusion. Thus, the interpretation that SENTIMENT ${ }^{\perp}$ predicts bond returns because bond-like stocks (and bonds) become "riskier" has already been tested and found wanting, so we do not repeat this exercise here.

On the other hand, how the predicted component of bond returns affects the cross-section of betas has yet to be examined. We run regressions of the form:

$$
r_{p t}-r_{f t}=c+d\left(r_{b t}-r_{f t}\right)^{*}+\beta\left(e+f\left(r_{b t}-r_{f t}\right)^{*}\right)\left(r_{m t}-r_{f t}\right)+u_{p t} .
$$


Again, the time-varying betas interpretation of why yield curve-based variables predict the relative returns on bond-like stocks (and bonds) requires that $\beta f$ be higher for such stocks. Table 8 reports the $\beta f$ coefficients alternative specifications of Eq. (5). We report results for the case where the Cochrane-Piazzesi method is used to predict bond returns; results for the CampbellShiller method are very similar. Table 8 shows that conditional changes in betas are indeed of the correct sign to explain, qualitatively, the earlier predictability results. For instance, when predicted bond returns are 1 percentage point higher per month and therefore predicted returns on speculative stocks are low, we find that betas on the smallest firms are lower by .20, on average, betas on the youngest firms are lower by .12, and betas on high-volatility firms are lower by $.22 .{ }^{5}$

Unfortunately, such changes in betas are far too small to explain the predictability results. There are two ways to see this. First, Table 6 shows that when predicted monthly bond returns are 1 percentage point higher, predicted monthly returns on small, young, and high-volatility stocks are $.55, .76$, and .86 percentage points lower, respectively. Simply dividing the changes in predicted returns by the changes in betas in the previous paragraph implies a monthly risk premium of roughly 2.75 to 6.33 percentage points. We extend this exercise regressing the predicted excess returns in Table 6 on the change in beta in Table 8. The implied risk premium is approximately 3.8 percentage points per month, or around 56 percentage points per year, an order of magnitude larger than risk premia typically suggested.

Given that changes in betas conditional on Campbell-Shiller predictions are similar (unreported), and that those conditional on SENTIMENT ${ }^{\perp}$ are in the wrong direction, we can conclude that changes in betas are at most a partial explanation. This means that if time-varying

\footnotetext{
${ }^{5}$ The fact that betas on average go down in Table 8 is an artifact of equal weighting. The average value-weighted beta remains at 1.00, which is enforced by a slight increase in the largest stocks' betas.
} 
rationally required returns are driving the predictability results, they must work primarily through a time-varying market risk premium.

This explanation also encounters significant problems, however. The results in Tables 5 and 6 indicate that the predicted returns on long-short stock portfolios often flip sign over time. For example, when predicted bond returns are high or SENTIMENT ${ }^{\perp}$ is high, the predicted returns on low-sigma stocks (profitable stocks, dividend payers) are actually higher than predicted returns on high-sigma stocks (or unprofitable stocks, nonpayers). ${ }^{6}$

The market risk premium cannot explain changes in sign unless the ranking of betas changes over time. As it turns out, drops of even 0.20 merely serve to narrow the gap between predicted returns on low- and high-sigma stocks, preserving the ranking of predicted returns over time. Given a fixed ranking of betas over time, changes in the market risk premium can only attenuate the differences in predicted returns. As long as the market risk premium is nonnegative, it cannot explain how the predicted returns on long-short stock portfolios flip sign over time. The bottom line is that the changes in betas offer some intriguing support for a rational explanation for the return predictability patterns in Tables 5 and 6, but it is an explanation that is incomplete.

\section{B. Evidence from mutual fund flows}

The cross-predictability results are difficult to explain with time-varying, rationally required returns, leaving room investor sentiment and occasional flights to quality. Of course, hypotheses based on investor sentiment are less rejectable by construction. Through an analysis of mutual fund flows, we attempt to provide more affirmative evidence for the existence of a

\footnotetext{
${ }^{6}$ For example, when the Cochrane-Piazzesi predicted excess bond return is below its mean, the average excess return on high volatility stocks (decile 10) is 1.21 percent per month and the excess return on low volatility stocks (decile 1) is 0.38 percent per month. By contrast, when the predicted excess bond return is above its mean, average excess return on low volatility stocks, at 1.15 percent per month, actually exceeds the excess return on high volatility stocks, at 0.84 percent per month.
} 
sentiment channel. The basic idea is that mutual fund investors are more likely to be prone to sentiment-based trading. Casual observation and prior research suggests that this is plausible. Many authors, such as Edwards and Zhang (1998) and Neal and Wheatley (1998), have pointed out that mutual fund investors tend to be smaller and less experienced than many other market participants. Gemmill and Thomas (2002) show that mutual fund flows are closely related to closed-end fund discounts, a common proxy for investor sentiment.

We use the pattern of flows across more "speculative" stock-oriented funds and "safer" government bond funds to construct a measure of retail investor sentiment in the spirit of the studies of mutual fund flows in Goetzmann, Massa, and Rouwenhorst (2000) and Brown, Goetzmann, Hiraki, Shiraishi, and Watanabe (2005). Then, we simply ask whether the relative return on bond-like stocks increases as mutual fund investors shift from speculative to safer funds, as predicted by a sentiment channel, or whether there is no such relationship.

Our data on flows into various categories of mutual funds are from the Investment Company Institute. They cover 1986 through 2004, a little less than half our full sample, at a monthly frequency. We consider net flows into "aggressive growth," "growth,” "growth and income," "balanced," “income equity,” and "government bond (all maturities)" funds. Intuitively, these objectives span the range of securities that interests us, from the riskier corners of the cross-section of stocks to government bonds. Monthly flows are defined as net sales minus redemptions, scaled by end-of-month total net assets. We scale by end-of-month net assets to correct for occasional changes in the ICI category definitions which would generate spurious outliers in a beginning-of-month scaling. See Warther (1995) for a detailed description of the ICI mutual fund flows data. 
We start with a principal components analysis of the fund flows, similar to Goetzmann et al. (2000). Not surprisingly, the first principal component, which explains 66.5 percent of the sample variance, is clearly a "general investment into mutual funds” effect. Standardized flows into each of the six fund objectives obtain strong positive weights in this component. The second principal component, which explains an additional 19.0 percent of the variance, appears to nicely capture the split between flows into funds that hold bonds and bond-like stocks and flows into funds holding more risky securities. The estimated weights are -0.457 for net flows into aggressive growth funds, -0.483 for growth, -0.041 for growth and income, 0.132 for balanced, 0.296 for income equity, and 0.572 for government bonds. ${ }^{7}$

The next question is whether the relative returns on bonds and bond-like stocks are related to relative inflows into mutual funds that hold such assets. We conduct regressions to test for this relationship, using specifications of the form

$$
r_{p t}-r_{f t}=a_{p}+\beta_{p}\left(r_{m t}-r_{f t}\right)+f_{p} M F F_{t}^{*}+u_{p t}
$$

where $M F F^{*}$ is the second principal component of mutual fund flows evaluated at month $t$ flows. The sentiment channel predicts that the coefficients $f_{p}$ will be more positive for bonds and bondlike stocks. $^{8}$

We start with bonds. In unreported results, we find that when $M F F^{*}$ increases, and thus mutual fund investors are leaning toward more conservative funds, excess long-term bond returns are also higher (estimated $f_{p}=0.38$, robust t-stat $=1.69$ ) by significantly more than predicted by the usual correlation between bonds and stocks. Excess intermediate-term bond

\footnotetext{
${ }^{7}$ Only these two principal components' eigenvalues are greater than 1.00 , which is the traditional hurdle for judging the usefulness of a component.

${ }^{8}$ Note that since principal components are orthogonal by construction, whether to add or exclude the first principal component of fund flows into Eq. (6) has little effect on the $f_{p}$ estimates.
} 
returns show a similar but slightly stronger pattern (estimated $f_{p}=0.26$, robust t-stat $=2.81$ ) These results are as predicted by a sentiment or flight-to-quality channel.

Table 9 shows the results for more general stock portfolios. Some of the strongest results involve the volatility-sorted portfolios. The lowest-risk decile has a significant positive coefficient on $M F F^{*}$, meaning that, when mutual fund flows strongly favor more conservative funds, then low-volatility stocks increase more than predicted by their usual beta with overall stock market returns. Likewise, there is a significantly negative coefficient on the highest-risk decile. When mutual fund flows strongly favor aggressive stock funds at the expense of bond funds, now it is high-risk stocks that increase more than usual.

More generally, the estimated coefficients in Panel A of Table 9 generally follow the predicted pattern. There are monotonic or nearly monotonic patterns also appearing for the size and profitability portfolios, while nonpayers and the youngest stocks also appear to do worst when mutual fund flows indicate a shift toward more conservative investments. There are also U-shaped patterns in the external finance and sales growth portfolios. However, unlike the coefficients in the extreme volatility portfolios, few these coefficients are statistically different from each other.

The fact that the volatility portfolios uncover the strongest results here is consistent with the fund flows being a noisy sentiment proxy. The idiosyncratic risk portfolios display the strongest results in most of our earlier exercises, and provide the most robust relationships with the investor sentiment measures examined in Baker and Wurgler (2005). In sum, the estimated coefficients are of the expected pattern, and those that are significant (including the coefficient on the long-term bond portfolio) are those that would seem most likely to emerge despite a noisy proxy for sentiment. 


\section{Conclusion}

Most asset pricing research tends to concentrate on either stock returns or bond returns, and those that do consider both categories at the same time have almost entirely ignored crossstock differences in the relationship between stocks and government bonds. In this paper, we document a set of strong, intuitive covariance patterns. Government bonds comove most strongly with “bond-like” stocks, i.e., stocks of large, long-listed, low-volatility, profitable, dividendpaying firms which are neither high growth nor distressed. More speculative categories of stocks_-stocks of smaller, newly-listed, high-volatility, unprofitable, nonpayers characterized by either high growth opportunities or distress - display a substantially lower correlation with bonds.

This pattern arises from some combination of common shocks to real cash flows, common shocks to rationally required returns, or common sentiment-driven mispricings. Consistent with the latter two effects, we find a common predictable component in bonds and bond-like stocks: Yield curve-based variables that predict bond returns also predict the relative returns of bond-like stocks, while sentiment proxies that predict the relative returns of bond-like stocks also predict bond returns. A closer look does not support time-varying rationally required returns as a complete explanation, however, leaving sentiment as a residual explanation. An analysis of mutual fund flows, which reflect the demands of a class of investors more prone to sentiment, offers some affirmative evidence for the existence of a sentiment channel. We conclude that part of the covariance relationship between government bonds and the crosssection of stocks reflects broad flight-to-quality-and-back patterns in investor demand. 


\section{References}

Baker, Malcolm, and Jeffrey Wurgler, 2005, Investor sentiment and the cross-section of stock returns, Journal of Finance, forthcoming.

Barberis, Nicholas, and Andrei Shleifer, 2003, Style investing, Journal of Financial Economics 68, 161-199.

Barsky, Robert B., 1989, Why don’t the prices of stocks and bonds move together?, American Economic Review 79, 1132-1145.

Brown, Gregory W., and Michael T. Cliff, 2004, Investor sentiment and the near-term stock market, Journal of Empirical Finance 11, 1-27.

Brown, Stephen J., William N. Goetzmann, Takato Hiraki, Noriyoshi Shiraishi, and Masahiro Watanabe, 2005, Investor sentiment in Japanese and U.S. daily mutual fund flows, New York University working paper.

Campbell, John Y., and John Ammer, 1993, What moves the stock and bond markets? A variance decomposition for long-term asset returns, Journal of Finance 48, 3-37.

Campbell, John Y., and Robert J. Shiller, 1991, Yield spreads and interest rate movements: A bird's eye view, Review of Economic Studies 58, 495-514.

Chordia, Tarun, Asani Sarkar, and Avanidhar Subrahmanyam, 2003, An empirical analysis of stock and bond market liquidity, Review of Financial Studies, forthcoming.

Cochrane, John, and Monika Piazzesi, 2005, Bond risk premia, American Economic Review 95, 138-160. 
Cohen, Randolph B., Christopher Polk, and Tuomo Vuolteenaho, 2004, Money illusion in the stock market: The Modigliani-Cohn hypothesis, Quarterly Journal of Economics, forthcoming.

Connolly, Robert, Chris Stivers, and Licheng Sun, 2005, Stock market uncertainty and the stockbond return relation, Journal of Financial and Quantitative Analysis 40, 161-194.

Edelen, Roger M., and Jerold B. Warner, 2001, Aggregate price effects of institutional trading: A study of mutual fund flow and market returns, Journal of Financial Economics 59, 195220.

Edwards, Franklin R., and Xin Zhang, 1998, Mutual funds and stock and bond market stability, Journal of Financial Services Research 13, 257-282.

Fama, Eugene F. and Robert R. Bliss, 1987, The information in long-maturity forward rates, American Economic Review 77, 680-692.

Fama, Eugene F. and Kenneth R. French, 1989, Business conditions and expected returns on bonds and stocks, Journal of Financial Economics 25, 23-49.

Fama, Eugene F., and Kenneth R. French, 1992, The cross-section of expected stock returns, Journal of Finance 47, 427-465.

Fama, Eugene F., and Kenneth R. French, 1993, Common risk factors in the returns on stocks and bonds, Journal of Financial Economics 33, 3-56.

Gemmill, Gordon, and Dylan C. Thomas, 2002, Noise trading, costly arbitrage, and asset prices: Evidence from closed-end funds, Journal of Finance 57, 2571-2594.

Goetzmann, William N., Massimo Massa, and K. Geert Rouwenhorst, 2000, Behavioral factors in mutual fund flows, Yale University working paper.

Gulko, Les, 2002, Decoupling, Journal of Portfolio Management 28, 59-66. 
Ibbotson Associates, 2005, Stocks, Bonds, Bills, and Inflation, (Ibbotson Associates, Chicago).

Shiller, Robert J., and Andrea E. Beltratti, 1992, Stock prices and bond yields: Can their comovements be explained in terms of present value models?, Journal of Monetary Economics 30, 25-46.

Warther, Vincent A., 1995, Aggregate mutual fund flows and security returns, Journal of Financial Economics 39, 209-235. 
Table 1. Summary statistics: Portfolios, 1963 to 2004. Means and standard deviations of monthly portfolio returns. For each month, we form ten portfolios according to the NYSE breakpoints of firm size (ME), age, total risk, earnings-book ratio for profitable firms (E/BE), dividend-book ratio for dividend payers (D/BE), fixed assets (PPE/A), research and development (RD/A), book-to-market ratio (BE/ME), external finance over assets (EF/A), and sales growth (GS). We also calculate portfolio returns for unprofitable firms, nonpayers, zero PP\&E firms, and zero R\&D firms. N=498.

\begin{tabular}{|c|c|c|c|c|c|c|c|c|c|c|c|}
\hline & \multirow[b]{2}{*}{$<\mathbf{0}$} & \multicolumn{10}{|c|}{ Decile } \\
\hline & & 1 & 2 & 3 & 4 & 5 & 6 & 7 & 8 & 9 & 10 \\
\hline \multicolumn{12}{|c|}{ Panel A. Means } \\
\hline $\mathrm{ME}$ & & 1.70 & 1.26 & 1.28 & 1.19 & 1.30 & 1.11 & 1.17 & 1.11 & 1.03 & 0.91 \\
\hline AGE & & 1.11 & 1.46 & 1.54 & 1.41 & 1.49 & 1.50 & 1.25 & 1.29 & 1.25 & 1.17 \\
\hline$\sigma$ & & 1.25 & 1.32 & 1.29 & 1.31 & 1.42 & 1.40 & 1.40 & 1.43 & 1.51 & 1.50 \\
\hline $\mathrm{D} / \mathrm{BE}$ & 1.49 & 1.52 & 1.41 & 1.49 & 1.36 & 1.34 & 1.27 & 1.26 & 1.18 & 1.17 & 1.16 \\
\hline $\mathrm{E} / \mathrm{BE}$ & 1.60 & 1.57 & 1.50 & 1.64 & 1.44 & 1.34 & 1.39 & 1.36 & 1.38 & 1.32 & 1.29 \\
\hline $\mathrm{BE} / \mathrm{ME}$ & & 0.77 & 1.06 & 1.17 & 1.25 & 1.34 & 1.45 & 1.58 & 1.63 & 1.82 & 2.04 \\
\hline $\mathrm{EF} / \mathrm{A}$ & & 1.87 & 1.67 & 1.63 & 1.53 & 1.46 & 1.41 & 1.33 & 1.30 & 1.31 & 0.86 \\
\hline GS & & 1.73 & 1.53 & 1.45 & 1.41 & 1.41 & 1.42 & 1.50 & 1.49 & 1.32 & 0.95 \\
\hline \multicolumn{12}{|c|}{ Panel B. Standard Deviations } \\
\hline ME & & 6.93 & 6.51 & 6.21 & 5.94 & 5.73 & 5.38 & 5.25 & 5.15 & 4.77 & 4.61 \\
\hline AGE & & 7.15 & 6.94 & 6.54 & 6.18 & 5.82 & 5.46 & 4.85 & 4.62 & 4.97 & 4.49 \\
\hline$\sigma$ & & 3.14 & 3.69 & 4.10 & 4.44 & 4.81 & 5.18 & 5.60 & 6.19 & 6.94 & 8.62 \\
\hline $\mathrm{D} / \mathrm{BE}$ & 7.64 & 5.78 & 5.41 & 5.10 & 4.91 & 4.68 & 4.52 & 4.18 & 3.96 & 3.89 & 4.06 \\
\hline $\mathrm{E} / \mathrm{BE}$ & 8.53 & 6.67 & 5.98 & 6.06 & 5.70 & 5.47 & 5.34 & 5.35 & 5.25 & 5.10 & 5.75 \\
\hline $\mathrm{BE} / \mathrm{ME}$ & & 7.48 & 6.47 & 6.05 & 5.75 & 5.44 & 5.30 & 5.17 & 5.22 & 5.58 & 6.34 \\
\hline $\mathrm{EF} / \mathrm{A}$ & & 6.47 & 5.61 & 5.23 & 5.07 & 4.98 & 5.06 & 5.25 & 5.51 & 6.10 & 7.79 \\
\hline GS & & 7.29 & 5.63 & 5.14 & 4.81 & 4.93 & 4.94 & 5.17 & 5.61 & 6.10 & 7.60 \\
\hline
\end{tabular}


Table 2. Summary statistics: Bond returns, 1963 to 2004. Means, medians, standard deviations, minima, and maxima of monthly bond yields and returns. The first panel presents bond yields. The first four rows use data from Ibbotson and Associates (2004) and are lagged six months relative to the returns data. The risk-free rate (Rf) is the yield computed from treasury bill returns; the terms spread is the difference between the long-term government bond yield and the treasury bill yield; the credit spread is the difference between the NBER commercial paper yield and the treasury bill yield; the credit term spread is the difference between the yield on Aaa bonds from Moody's investor service and the commercial paper yield. The next five rows are forwards derived from the Fama-Bliss yield curve and are twelve-month moving averages lagged once relative to the returns data. The second panel presents bond returns. Both rows use data from Ibbotson and Associates (2004). The excess return on intermediate-term bonds $\left(\mathrm{R}_{\mathrm{IT}}-\mathrm{R}_{\mathrm{f}}\right)$ is the difference between the intermediate-term government bond return and the treasury bill return; the excess return on long-term bonds $\left(\mathrm{R}_{\mathrm{LT}}-\mathrm{R}_{\mathrm{f}}\right)$ is the difference between the long-term government bond return and the treasury bill return. $\mathrm{N}=498$.

\begin{tabular}{lcccrr}
\hline & Mean & Median & STD & Min & Max \\
\hline Panel A. Yield Curve & & & & & \\
\hline $\mathrm{R}_{\mathrm{f}}$ & 5.93 & 5.37 & 2.88 & 0.72 & 17.42 \\
Term spread & 1.60 & 1.57 & 1.68 & -5.40 & 5.52 \\
Credit spread & 0.60 & 0.50 & 0.77 & -2.50 & 4.41 \\
Credit term spread & 0.65 & 0.59 & 0.40 & -0.53 & 2.02 \\
1-year & 6.39 & 5.93 & 2.66 & 1.20 & 14.18 \\
2-year forward & 6.83 & 6.45 & 2.57 & 1.98 & 14.02 \\
3-year forward & 7.14 & 6.75 & 2.40 & 3.01 & 14.15 \\
4-year forward & 7.34 & 7.05 & 2.38 & 3.85 & 13.95 \\
5-year forward & 7.32 & 7.02 & 2.32 & 4.02 & 13.17 \\
\hline Panel B. Returns & & & & & \\
\hline $\mathrm{R}_{\mathrm{IT}}-\mathrm{R}_{\mathrm{f}}$ & 0.14 & 0.09 & 1.57 & -7.30 & 10.73 \\
$\mathrm{R}_{\mathrm{LT}}-\mathrm{R}_{\mathrm{f}}$ & 0.17 & 0.05 & 2.89 & -9.89 & 13.98 \\
\hline
\end{tabular}


Table 3. Bond returns and the cross-section of stock returns. We regress monthly excess portfolio returns on contemporaneous excess market returns and excess long-term bond returns:

$$
r_{p t}-r_{f t}=a_{p}+\beta_{p}\left(r_{m t}-r_{f t}\right)+b_{p}\left(r_{b t}-r_{f t}\right)+u_{p t}
$$

We report only $b_{p}$. The portfolios are formed equally-weighted within deciles on market capitalization (ME), age or years since CRSP listing (AGE), monthly volatility $(\sigma)$, dividends scaled by book equity (D/BE), profits scaled by book equity (E/BE), book-to-market ratio (BE/ME), external finance scaled by assets (EF/A), sales growth (GS). $\mathrm{N}=498$.

\begin{tabular}{|c|c|c|c|c|c|c|c|c|c|c|c|}
\hline & \multirow[b]{2}{*}{$<\mathbf{0}$} & \multicolumn{10}{|c|}{ Decile } \\
\hline & & 1 & 2 & 3 & 4 & 5 & 6 & 7 & 8 & 9 & 10 \\
\hline \multicolumn{12}{|c|}{ Panel A. Coefficients } \\
\hline $\mathrm{ME}$ & & -0.32 & -0.22 & -0.17 & -0.16 & -0.14 & -0.06 & -0.02 & 0.00 & 0.06 & 0.03 \\
\hline AGE & & -0.38 & -0.27 & -0.21 & -0.18 & -0.12 & -0.12 & -0.05 & 0.03 & -0.02 & -0.03 \\
\hline$\sigma$ & & 0.17 & 0.10 & 0.02 & 0.00 & -0.06 & -0.11 & -0.16 & -0.24 & -0.29 & -0.45 \\
\hline $\mathrm{D} / \mathrm{BE}$ & -0.39 & -0.15 & -0.09 & -0.07 & -0.04 & 0.01 & 0.04 & 0.08 & 0.12 & 0.14 & 0.05 \\
\hline $\mathrm{E} / \mathrm{BE}$ & -0.47 & -0.31 & -0.17 & -0.15 & -0.15 & -0.10 & -0.09 & -0.09 & -0.07 & -0.06 & -0.14 \\
\hline $\mathrm{BE} / \mathrm{ME}$ & & -0.36 & -0.25 & -0.22 & -0.18 & -0.15 & -0.10 & -0.14 & -0.11 & -0.14 & -0.24 \\
\hline $\mathrm{EF} / \mathrm{A}$ & & -0.27 & -0.21 & -0.13 & -0.13 & -0.09 & -0.07 & -0.11 & -0.13 & -0.19 & -0.37 \\
\hline GS & & -0.36 & -0.20 & -0.12 & -0.07 & -0.08 & -0.07 & -0.11 & -0.15 & -0.21 & -0.37 \\
\hline \multicolumn{12}{|c|}{ Panel B. T-statistics } \\
\hline $\mathrm{ME}$ & & {$[-4.5]$} & {$[-4.4]$} & {$[-3.9]$} & {$[-4.0]$} & {$[-4.2]$} & {$[-1.9]$} & {$[-1.0]$} & {$[-0.2]$} & {$[2.9]$} & [1.9] \\
\hline AGE & & {$[-6.1]$} & {$[-4.5]$} & {$[-4.1]$} & {$[-3.4]$} & {$[-2.5]$} & {$[-2.9]$} & {$[-1.3]$} & {$[0.8]$} & {$[-0.5]$} & [-0.9] \\
\hline$\sigma$ & & [4.4] & [3.1] & [0.7] & {$[0.1]$} & {$[-1.7]$} & {$[-2.8]$} & {$[-3.7]$} & {$[-4.8]$} & {$[-4.9]$} & {$[-5.6]$} \\
\hline $\mathrm{D} / \mathrm{BE}$ & {$[-5.6]$} & {$[-3.2]$} & {$[-2.1]$} & {$[-1.6]$} & {$[-0.9]$} & [0.3] & [1.0] & [2.4] & [3.8] & [5.3] & [1.7] \\
\hline $\mathrm{E} / \mathrm{BE}$ & {$[-5.5]$} & {$[-4.8]$} & {$[-3.2]$} & {$[-2.6]$} & {$[-3.0]$} & {$[-2.1]$} & {$[-2.1]$} & {$[-2.0]$} & {$[-1.8]$} & {$[-1.5]$} & [-3.3] \\
\hline $\mathrm{BE} / \mathrm{ME}$ & & {$[-5.9]$} & {$[-5.1]$} & {$[-4.8]$} & {$[-4.0]$} & {$[-3.5]$} & {$[-2.4]$} & {$[-3.2]$} & {$[-2.4]$} & {$[-2.7]$} & {$[-3.8]$} \\
\hline $\mathrm{EF} / \mathrm{A}$ & & {$[-4.5]$} & {$[-4.3]$} & {$[-3.2]$} & {$[-3.3]$} & {$[-2.4]$} & {$[-1.9]$} & {$[-2.8]$} & {$[-3.2]$} & {$[-4.1]$} & {$[-5.5]$} \\
\hline GS & & {$[-4.9]$} & {$[-3.8]$} & [-2.9] & {$[-1.7]$} & {$[-2.0]$} & [-1.9] & {$[-2.9]$} & {$[-3.6]$} & [-4.7] & {$[-5.9]$} \\
\hline
\end{tabular}


Table 4. Predictable variation in bond returns. We regress monthly excess intermediate- and long-term government bonds on the term structure of interest rates. Campbell and Shiller (1988) use the level and slope of the term structure to predict returns, while Cochrane and Piazzesi (2004) use the five Fama-Bliss forward rates. The last set of columns uses the fixed factor from Cochrane and Piazzesi (2004). N=498.

\begin{tabular}{|c|c|c|c|c|c|c|c|c|c|c|c|c|}
\hline & \multicolumn{4}{|c|}{ Augmented Campbell-Shiller } & \multicolumn{4}{|c|}{ Cochrane-Piazzesi } & \multicolumn{4}{|c|}{ Cochrane-Piazzesi Factor } \\
\hline & \multicolumn{2}{|c|}{ Long-Term } & \multicolumn{2}{|c|}{ Intermediate } & \multicolumn{2}{|c|}{ Long-Term } & \multicolumn{2}{|c|}{ Intermediate } & \multicolumn{2}{|c|}{ Long-Term } & \multicolumn{2}{|c|}{ Intermediate } \\
\hline & Coef & [t] & Coef & [t] & Coef & [t] & Coef & [t] & Coef & [t] & Coef & [t] \\
\hline $\mathrm{R}_{\mathrm{f}}$ & 0.10 & {$[1.77]$} & 0.06 & [2.05] & & & & & & & & \\
\hline Term spread & 0.33 & {$[3.56]$} & 0.15 & [2.95] & & & & & & & & \\
\hline Credit spread & 0.16 & {$[0.95]$} & 0.03 & [0.33] & & & & & & & & \\
\hline Credit term spread & 0.47 & {$[1.45]$} & 0.30 & [1.69] & & & & & & & & \\
\hline 1-year & & & & & -0.88 & {$[-2.54]$} & -0.42 & {$[-2.22]$} & & & & \\
\hline 2-year forward & & & & & 0.63 & {$[0.78]$} & 0.12 & {$[0.28]$} & & & & \\
\hline 3-year forward & & & & & 0.77 & {$[1.00]$} & 0.81 & [1.97] & & & & \\
\hline 4-year forward & & & & & 0.83 & [1.51] & 0.34 & [1.15] & & & & \\
\hline 5-year forward & & & & & -1.30 & {$[-3.28]$} & -0.82 & {$[-3.83]$} & & & & \\
\hline CP Factor & & & & & & & & & 0.18 & {$[5.11]$} & 0.33 & [5.01] \\
\hline $\mathrm{N}$ & & 498 & & 498 & & 498 & & 498 & & 498 & & 498 \\
\hline $\mathrm{R}^{2}$ & & 0.03 & & 0.02 & & 0.05 & & 0.06 & & 0.05 & & 0.05 \\
\hline
\end{tabular}


Table 5. Predictable variation (Augmented Campbell-Shiller) in bond returns and the cross-section of stock returns. We regress monthly excess portfolio returns on contemporaneous excess market returns and the predictable component of bond returns:

$$
r_{p t}-r_{f t}=a_{p}+\beta_{p}\left(r_{m t}-r_{f t}\right)+t_{p}\left(r_{b t}-r_{f t}\right)^{*}+u_{p t}
$$

We report only $t_{p}$. The portfolios are formed equally-weighted within deciles on market capitalization (ME), age or years since CRSP listing (AGE), monthly volatility $(\sigma)$, dividends scaled by book equity (D/BE), profits scaled by book equity (E/BE), book-to-market ratio (BE/ME), external finance scaled by assets (EF/A), sales growth (GS). $\mathrm{N}=498$.

\begin{tabular}{|c|c|c|c|c|c|c|c|c|c|c|c|}
\hline & \multirow[b]{2}{*}{$<0$} & \multicolumn{10}{|c|}{ Decile } \\
\hline & & 1 & 2 & 3 & 4 & 5 & 6 & 7 & 8 & 9 & 10 \\
\hline \multicolumn{12}{|c|}{ Panel A. Coefficients } \\
\hline $\mathrm{ME}$ & & -0.46 & -0.31 & -0.17 & 0.00 & -0.15 & 0.13 & 0.09 & 0.10 & 0.13 & 0.09 \\
\hline AGE & & -0.49 & -0.06 & -0.03 & 0.24 & 0.35 & 0.11 & 0.23 & 0.22 & 0.19 & 0.13 \\
\hline$\sigma$ & & 0.75 & 0.64 & 0.45 & 0.24 & 0.22 & 0.01 & -0.05 & -0.23 & -0.46 & -0.79 \\
\hline $\mathrm{D} / \mathrm{BE}$ & -0.80 & -0.15 & 0.12 & 0.25 & 0.24 & 0.36 & 0.42 & 0.37 & 0.46 & 0.28 & 0.25 \\
\hline $\mathrm{E} / \mathrm{BE}$ & -0.90 & -0.51 & -0.37 & -0.40 & -0.02 & 0.09 & 0.01 & 0.11 & 0.24 & 0.13 & -0.15 \\
\hline $\mathrm{BE} / \mathrm{ME}$ & & -0.84 & -0.25 & -0.06 & 0.22 & 0.15 & 0.06 & 0.00 & -0.04 & -0.12 & 0.17 \\
\hline $\mathrm{EF} / \mathrm{A}$ & & -0.29 & -0.08 & 0.25 & 0.33 & 0.14 & 0.23 & 0.17 & 0.14 & -0.16 & -0.60 \\
\hline GS & & -0.54 & 0.31 & 0.31 & 0.30 & 0.37 & 0.23 & 0.11 & -0.10 & -0.09 & -0.66 \\
\hline \multicolumn{12}{|c|}{ Panel B. T-statistics } \\
\hline ME & & {$[-1.2]$} & {$[-1.1]$} & {$[-0.7]$} & {$[0.0]$} & {$[-0.8]$} & {$[0.8]$} & {$[0.7]$} & {$[0.8]$} & {$[1.3]$} & [1.1] \\
\hline AGE & & {$[-1.5]$} & {$[-0.2]$} & {$[-0.1]$} & [1.0] & {$[1.5]$} & {$[0.6]$} & [1.3] & {$[1.3]$} & {$[0.9]$} & [1.0] \\
\hline$\sigma$ & & [4.7] & {$[4.6]$} & [3.1] & {$[1.5]$} & {$[1.2]$} & {$[0.1]$} & {$[-0.2]$} & {$[-0.9]$} & {$[-1.5]$} & {$[-1.9]$} \\
\hline $\mathrm{D} / \mathrm{BE}$ & {$[-2.1]$} & {$[-0.6]$} & {$[0.6]$} & [1.2] & {$[1.2]$} & {$[2.0]$} & {$[2.6]$} & {$[2.5]$} & [3.4] & {$[2.1]$} & [1.7] \\
\hline $\mathrm{E} / \mathrm{BE}$ & {$[-1.9]$} & {$[-1.4]$} & {$[-1.2]$} & {$[-1.0]$} & {$[-0.1]$} & {$[0.3]$} & {$[0.0]$} & {$[0.5]$} & {$[1.1]$} & {$[0.7]$} & {$[-0.7]$} \\
\hline $\mathrm{BE} / \mathrm{ME}$ & & {$[-3.0]$} & {$[-1.1]$} & {$[-0.3]$} & {$[0.9]$} & {$[0.6]$} & {$[0.2]$} & {$[0.0]$} & {$[-0.2]$} & {$[-0.4]$} & {$[0.5]$} \\
\hline $\mathrm{EF} / \mathrm{A}$ & & {$[-0.9]$} & {$[-0.3]$} & {$[1.2]$} & {$[1.6]$} & {$[0.8]$} & {$[1.2]$} & {$[0.9]$} & {$[0.7]$} & {$[-0.7]$} & {$[-1.8]$} \\
\hline GS & & {$[-1.5]$} & {$[1.2]$} & [1.5] & {$[1.6]$} & [1.9] & {$[1.2]$} & {$[0.5]$} & {$[-0.5]$} & {$[-0.4]$} & {$[-2.1]$} \\
\hline
\end{tabular}


Table 6. Predictable variation (Cochrane-Piazzesi) in bond returns and the cross-section of stock returns. We regress monthly excess portfolio returns on contemporaneous excess market returns and the predictable component of bond returns:

$$
r_{p t}-r_{f t}=a_{p}+\beta_{p}\left(r_{m t}-r_{f t}\right)+t_{p}\left(r_{b t}-r_{f t}\right)^{*}+u_{p t}
$$

We report only $t_{p}$. The portfolios are formed equally-weighted within deciles on market capitalization (ME), age or years since CRSP listing (AGE), monthly volatility $(\sigma)$, dividends scaled by book equity (D/BE), profits scaled by book equity (E/BE), book-to-market ratio (BE/ME), external finance scaled by assets (EF/A), sales growth (GS). $\mathrm{N}=498$.

\begin{tabular}{|c|c|c|c|c|c|c|c|c|c|c|c|}
\hline & \multirow[b]{2}{*}{$<\mathbf{0}$} & \multicolumn{10}{|c|}{ Decile } \\
\hline & & 1 & 2 & 3 & 4 & 5 & 6 & 7 & 8 & 9 & 10 \\
\hline \multicolumn{12}{|c|}{ Panel A. Coefficients } \\
\hline $\mathrm{ME}$ & & -0.55 & -0.44 & -0.44 & -0.38 & -0.34 & -0.16 & -0.22 & -0.15 & -0.09 & 0.06 \\
\hline AGE & & -0.76 & -0.50 & -0.25 & -0.24 & -0.10 & -0.26 & -0.09 & 0.06 & -0.21 & -0.12 \\
\hline$\sigma$ & & 0.43 & 0.29 & 0.14 & -0.04 & -0.08 & -0.22 & -0.33 & -0.52 & -0.70 & -0.86 \\
\hline $\mathrm{D} / \mathrm{BE}$ & -0.86 & -0.38 & -0.17 & -0.05 & -0.04 & 0.10 & 0.15 & 0.14 & 0.25 & 0.20 & 0.19 \\
\hline $\mathrm{E} / \mathrm{BE}$ & -0.92 & -0.65 & -0.42 & -0.37 & -0.22 & -0.10 & -0.18 & -0.21 & -0.10 & -0.13 & -0.39 \\
\hline $\mathrm{BE} / \mathrm{ME}$ & & -0.93 & -0.57 & -0.37 & -0.26 & -0.22 & -0.20 & -0.24 & -0.16 & -0.29 & -0.17 \\
\hline $\mathrm{EF} / \mathrm{A}$ & & -0.58 & -0.34 & -0.14 & -0.12 & -0.13 & -0.21 & -0.10 & -0.15 & -0.37 & -0.77 \\
\hline GS & & -0.71 & -0.20 & -0.10 & -0.06 & -0.01 & -0.05 & -0.11 & -0.28 & -0.43 & -0.86 \\
\hline \multicolumn{12}{|c|}{ Panel B. T-statistics } \\
\hline ME & & {$[-1.8]$} & {$[-2.1]$} & {$[-2.5]$} & {$[-2.4]$} & {$[-2.3]$} & {$[-1.3]$} & {$[-2.4]$} & {$[-1.6]$} & {$[-1.1]$} & {$[0.9]$} \\
\hline AGE & & {$[-3.0]$} & {$[-2.0]$} & {$[-1.1]$} & {$[-1.1]$} & {$[-0.5]$} & {$[-1.6]$} & {$[-0.7]$} & {$[0.4]$} & {$[-1.5]$} & {$[-1.1]$} \\
\hline$\sigma$ & & [3.2] & [2.7] & {$[1.2]$} & {$[-0.3]$} & {$[-0.5]$} & {$[-1.4]$} & {$[-1.8]$} & {$[-2.5]$} & {$[-2.9]$} & {$[-2.6]$} \\
\hline $\mathrm{D} / \mathrm{BE}$ & {$[-3.0]$} & {$[-2.1]$} & {$[-1.0]$} & {$[-0.3]$} & {$[-0.2]$} & {$[0.7]$} & [1.1] & {$[1.2]$} & {$[2.2]$} & [1.6] & [1.5] \\
\hline $\mathrm{E} / \mathrm{BE}$ & {$[-2.5]$} & {$[-2.2]$} & {$[-1.8]$} & {$[-1.3]$} & {$[-1.0]$} & {$[-0.5]$} & {$[-1.0]$} & {$[-1.2]$} & {$[-0.6]$} & {$[-0.9]$} & {$[-2.4]$} \\
\hline $\mathrm{BE} / \mathrm{ME}$ & & {$[-4.3]$} & {$[-3.1]$} & {$[-2.0]$} & {$[-1.4]$} & {$[-1.3]$} & {$[-1.2]$} & {$[-1.3]$} & {$[-0.8]$} & {$[-1.4]$} & {$[-0.6]$} \\
\hline $\mathrm{EF} / \mathrm{A}$ & & {$[-2.2]$} & {$[-1.6]$} & {$[-0.8]$} & {$[-0.7]$} & {$[-0.9]$} & {$[-1.5]$} & {$[-0.7]$} & {$[-0.9]$} & {$[-2.0]$} & {$[-3.0]$} \\
\hline GS & & {$[-2.3]$} & {$[-1.0]$} & {$[-0.5]$} & {$[-0.4]$} & {$[-0.1]$} & {$[-0.4]$} & {$[-0.7]$} & {$[-1.7]$} & {$[-2.4]$} & {$[-3.6]$} \\
\hline
\end{tabular}


Table 7. Sentiment and future bond returns. We regress excess bond returns on four factors, the predictable component of bond returns, and lagged SENTIMENT ${ }^{\perp}$ :

$$
r_{b t}-r_{f t}=a+\beta\left(r_{m t}-r_{f t}\right)+b\left(r_{b t}-r_{f t}\right)^{*}+\operatorname{sSENTIMENT} T_{t-1}^{\perp}+u_{t}
$$

We report results for long-term and intermediate term bonds. Excess bond return predictions are formed using the six-month lagged term spread and the six-month lagged treasury bill yield. $\mathrm{N}=498$.

\begin{tabular}{|c|c|c|c|c|c|c|c|c|}
\hline & \multicolumn{4}{|c|}{ Long Term Bond Returns } & \multicolumn{4}{|c|}{ Intermediate Term Bond Returns } \\
\hline & Coef & [t] & Coef & [t] & Coef & [t] & Coef & [t] \\
\hline \multicolumn{9}{|c|}{ Panel A. Campbell-Shiller } \\
\hline $\mathrm{a}$ & 0.09 & {$[0.7]$} & -0.05 & {$[-0.4]$} & 0.11 & {$[1.6]$} & 0.05 & {$[0.7]$} \\
\hline$\beta$ & 0.16 & [4.3] & 0.15 & [4.2] & 0.06 & [3.4] & 0.06 & [3.3] \\
\hline s & 0.26 & {$[2.2]$} & 0.14 & [1.2] & 0.17 & {$[2.8]$} & 0.12 & [1.9] \\
\hline $\mathrm{b}$ & & & 0.86 & [3.2] & & & 0.35 & [2.4] \\
\hline $\mathrm{N}$ & 498 & & 498 & & 498 & & 498 & \\
\hline $\mathrm{R}^{2}$ & 0.07 & & 0.09 & & 0.04 & & 0.05 & \\
\hline \multicolumn{9}{|c|}{ Panel B. Cochrane-Piazzesi } \\
\hline $\mathrm{a}$ & & & -0.05 & {$[-0.4]$} & & & 0.03 & {$[0.4]$} \\
\hline$\beta$ & & & 0.15 & [4.0] & & & 0.06 & [3.1] \\
\hline s & & & 0.15 & [1.3] & & & 0.11 & [1.8] \\
\hline $\mathrm{b}$ & & & 0.88 & [3.8] & & & 0.49 & [3.6] \\
\hline $\mathrm{N}$ & & & 498 & & & & 498 & \\
\hline $\mathrm{R}^{2}$ & & & 0.11 & & & & 0.09 & \\
\hline
\end{tabular}


Table 8. Predictable variation (Cochrane-Piazzesi) in bond returns and the cross-section of factor loadings. We regress monthly excess portfolio returns on contemporaneous excess market returns and the interaction between the predictable component of bond returns and excess market returns:

$$
r_{p t}-r_{f t}=a_{p}+\beta_{p}\left(c_{p}+d_{p}\left(r_{b t}-r_{f t}\right)^{*}\right)\left(r_{m t}-r_{f t}\right)+t_{p}\left(r_{b t}-r_{f t}\right)^{*}+u_{p t}
$$

We report only $\beta_{\mathrm{p}} \mathrm{d}_{\mathrm{p}}$. The portfolios are formed equally-weighted within deciles on market capitalization (ME), age or years since CRSP listing (AGE), monthly volatility $(\sigma)$, dividends scaled by book equity (D/BE), profits scaled by book equity (E/BE), book-to-market ratio (BE/ME), external finance scaled by assets (EF/A), sales growth (GS).

\begin{tabular}{|c|c|c|c|c|c|c|c|c|c|c|c|}
\hline & \multirow[b]{2}{*}{$<0$} & \multicolumn{10}{|c|}{ Decile } \\
\hline & & 1 & 2 & 3 & 4 & 5 & 6 & 7 & 8 & 9 & 10 \\
\hline \multicolumn{12}{|c|}{ Panel A. Coefficients } \\
\hline $\mathrm{ME}$ & & -0.20 & -0.12 & -0.07 & -0.05 & -0.02 & -0.03 & -0.03 & 0.01 & 0.03 & 0.02 \\
\hline AGE & & -0.12 & -0.12 & -0.11 & -0.11 & -0.05 & -0.09 & -0.04 & -0.07 & -0.10 & 0.00 \\
\hline$\sigma$ & & -0.05 & -0.03 & -0.04 & -0.07 & -0.07 & -0.09 & -0.09 & -0.15 & -0.17 & -0.22 \\
\hline $\mathrm{D} / \mathrm{BE}$ & -0.23 & -0.15 & -0.13 & -0.09 & -0.07 & -0.05 & -0.05 & -0.06 & -0.07 & -0.02 & -0.01 \\
\hline $\mathrm{E} / \mathrm{BE}$ & -0.22 & -0.21 & -0.15 & -0.13 & -0.11 & -0.13 & -0.12 & -0.16 & -0.13 & -0.13 & -0.14 \\
\hline $\mathrm{BE} / \mathrm{ME}$ & & -0.18 & -0.12 & -0.09 & -0.07 & -0.08 & -0.07 & -0.09 & -0.11 & -0.13 & -0.16 \\
\hline $\mathrm{EF} / \mathrm{A}$ & & -0.19 & -0.12 & -0.10 & -0.08 & -0.09 & -0.09 & -0.10 & -0.09 & -0.12 & -0.16 \\
\hline GS & & -0.17 & -0.10 & -0.10 & -0.07 & -0.10 & -0.09 & -0.11 & -0.13 & -0.13 & -0.15 \\
\hline \multicolumn{12}{|c|}{ Panel B. T-statistics } \\
\hline $\mathrm{ME}$ & & {$[-2.5]$} & {$[-1.9]$} & {$[-1.3]$} & {$[-1.0]$} & {$[-0.4]$} & {$[-0.8]$} & {$[-0.9]$} & {$[0.5]$} & {$[1.5]$} & {$[0.7]$} \\
\hline AGE & & {$[-1.8]$} & {$[-1.8]$} & {$[-1.6]$} & {$[-1.9]$} & {$[-1.0]$} & {$[-1.9]$} & {$[-0.9]$} & {$[-1.8]$} & {$[-2.6]$} & {$[-0.1]$} \\
\hline$\sigma$ & & {$[-1.5]$} & {$[-0.9]$} & {$[-1.2]$} & {$[-1.6]$} & {$[-1.5]$} & {$[-1.8]$} & {$[-1.7]$} & {$[-2.5]$} & {$[-2.5]$} & {$[-2.5]$} \\
\hline $\mathrm{D} / \mathrm{BE}$ & {$[-2.9]$} & {$[-2.6]$} & {$[-2.3]$} & {$[-1.7]$} & {$[-1.5]$} & {$[-1.0]$} & {$[-1.2]$} & {$[-1.6]$} & {$[-1.9]$} & {$[-0.7]$} & {$[-0.2]$} \\
\hline $\mathrm{E} / \mathrm{BE}$ & {$[-2.3]$} & {$[-2.6]$} & {$[-2.2]$} & {$[-2.0]$} & {$[-1.9]$} & {$[-2.2]$} & {$[-2.3]$} & {$[-2.9]$} & {$[-2.7]$} & {$[-3.2]$} & {$[-3.0]$} \\
\hline $\mathrm{BE} / \mathrm{ME}$ & & {$[-3.8]$} & {$[-2.7]$} & {$[-1.7]$} & {$[-1.2]$} & {$[-1.5]$} & {$[-1.3]$} & {$[-1.6]$} & {$[-1.8]$} & {$[-2.0]$} & {$[-2.0]$} \\
\hline $\mathrm{EF} / \mathrm{A}$ & & {$[-2.7]$} & {$[-2.0]$} & {$[-1.9]$} & {$[-1.6]$} & {$[-1.9]$} & {$[-1.9]$} & {$[-2.2]$} & {$[-1.9]$} & {$[-2.3]$} & {$[-2.3]$} \\
\hline GS & & {$[-2.2]$} & {$[-1.7]$} & {$[-1.8]$} & {$[-1.3]$} & {$[-2.0]$} & {$[-1.9]$} & {$[-2.3]$} & {$[-2.7]$} & {$[-2.6]$} & {$[-2.4]$} \\
\hline
\end{tabular}


Table 9. Mutual fund flows (1986 to 2004) and the cross-section of stock returns. We regress monthly excess portfolio returns on contemporaneous mutual fund flows:

$$
r_{p t}-r_{f t}=a_{p}+\beta_{p}\left(r_{m t}-r_{f t}\right)+f_{p} M F F_{t}^{*}+u_{p t}
$$

We report only $\mathrm{f}_{\mathrm{p}}$. The portfolios are formed equally-weighted within deciles on market capitalization (ME), age or years since CRSP listing (AGE), monthly volatility $(\sigma)$, dividends scaled by book equity (D/BE), profits scaled by book equity (E/BE), book-to-market ratio (BE/ME), external finance scaled by assets (EF/A), sales growth (GS). The mutual fund flow factor is the second principal component of the flows (scaled by ending assets) into aggressive growth, growth and income, income, and bond mutual funds. $\mathrm{N}=228$.

\begin{tabular}{|c|c|c|c|c|c|c|c|c|c|c|c|}
\hline & & \multicolumn{10}{|c|}{ Decile } \\
\hline & $<\mathbf{0}$ & 1 & 2 & 3 & 4 & 5 & 6 & 7 & 8 & 9 & 10 \\
\hline \multicolumn{12}{|c|}{ Panel A. Coefficients } \\
\hline $\mathrm{ME}$ & & -0.59 & -0.36 & -0.19 & -0.13 & -0.18 & -0.03 & -0.10 & -0.10 & 0.04 & -0.04 \\
\hline AGE & & -0.38 & -0.39 & -0.46 & -0.38 & -0.39 & -0.34 & -0.27 & -0.09 & 0.03 & 0.01 \\
\hline$\sigma$ & & 0.23 & 0.15 & 0.09 & -0.07 & -0.07 & -0.18 & -0.29 & -0.41 & -0.61 & -0.82 \\
\hline $\mathrm{D} / \mathrm{BE}$ & -0.59 & -0.17 & -0.07 & 0.06 & 0.04 & 0.12 & 0.04 & 0.16 & 0.16 & 0.10 & -0.08 \\
\hline $\mathrm{E} / \mathrm{BE}$ & -0.77 & -0.45 & -0.43 & -0.41 & -0.25 & -0.32 & -0.20 & -0.12 & -0.14 & -0.09 & -0.14 \\
\hline $\mathrm{BE} / \mathrm{ME}$ & & -0.41 & -0.28 & -0.47 & -0.25 & -0.37 & -0.24 & -0.31 & -0.33 & -0.35 & -0.60 \\
\hline $\mathrm{EF} / \mathrm{A}$ & & -0.68 & -0.43 & -0.31 & -0.39 & -0.19 & -0.26 & -0.18 & -0.31 & -0.33 & -0.47 \\
\hline GS & & -0.90 & -0.48 & -0.32 & -0.18 & -0.18 & -0.17 & -0.14 & -0.26 & -0.40 & -0.41 \\
\hline \multicolumn{12}{|c|}{ Panel B. T-statistics } \\
\hline $\mathrm{ME}$ & & {$[-1.6]$} & {$[-1.3]$} & {$[-0.9]$} & {$[-0.7]$} & {$[-1.1]$} & {$[-0.2]$} & {$[-0.9]$} & {$[-0.9]$} & {$[0.4]$} & {$[-0.3]$} \\
\hline $\mathrm{AGE}$ & & {$[-1.1]$} & {$[-1.1]$} & {$[-1.4]$} & {$[-1.5]$} & {$[-1.6]$} & {$[-1.6]$} & {$[-1.5]$} & {$[-0.7]$} & {$[0.2]$} & {$[0.1]$} \\
\hline$\sigma$ & & {$[1.8]$} & {$[1.3]$} & {$[0.8]$} & {$[-0.6]$} & {$[-0.5]$} & {$[-1.3]$} & {$[-1.4]$} & {$[-1.6]$} & {$[-1.9]$} & {$[-1.6]$} \\
\hline $\mathrm{D} / \mathrm{BE}$ & {$[-1.7]$} & {$[-1.0]$} & {$[-0.4]$} & {$[0.4]$} & {$[0.3]$} & {$[0.9]$} & {$[0.3]$} & {$[1.1]$} & {$[1.1]$} & {$[0.7]$} & {$[-0.5]$} \\
\hline $\mathrm{E} / \mathrm{BE}$ & {$[-1.6]$} & {$[-1.6]$} & {$[-2.0]$} & {$[-2.0]$} & {$[-1.1]$} & {$[-1.4]$} & {$[-1.2]$} & {$[-0.8]$} & {$[-1.0]$} & {$[-0.7]$} & {$[-0.9]$} \\
\hline $\mathrm{BE} / \mathrm{ME}$ & & {$[-1.1]$} & {$[-1.0]$} & {$[-1.9]$} & {$[-1.2]$} & {$[-2.0]$} & {$[-1.3]$} & {$[-1.7]$} & {$[-1.6]$} & {$[-1.5]$} & {$[-1.8]$} \\
\hline $\mathrm{EF} / \mathrm{A}$ & & {$[-2.3]$} & {$[-1.8]$} & {$[-1.4]$} & {$[-1.9]$} & {$[-1.2]$} & {$[-1.7]$} & {$[-1.0]$} & {$[-1.6]$} & {$[-1.3]$} & {$[-1.2]$} \\
\hline GS & & {$[-1.9]$} & {$[-1.9]$} & {$[-1.6]$} & {$[-1.2]$} & {$[-1.2]$} & {$[-1.1]$} & {$[-0.9]$} & {$[-1.4]$} & {$[-1.8]$} & {$[-1.2]$} \\
\hline
\end{tabular}


Figure 1. Bond returns and the cross-section of stock returns. We regress excess portfolio returns on contemporaneous excess market returns and excess long-term bond returns:

$$
r_{p t}-r_{f t}=a_{p}+\beta_{p}\left(r_{m t}-r_{f t}\right)+s_{p} S M B_{t}+h_{p} H M L_{t}+m_{p} U M D_{t}+b_{p}\left(r_{b t}-r_{f t}\right)+u_{p t}
$$

We report only $b_{p}$. The portfolios are formed equally-weighted within deciles on market capitalization (ME), age or years since CRSP listing (AGE), monthly volatility $(\sigma)$, dividends scaled by book equity (D/BE), profits scaled by book equity (E/BE), book-to-market ratio (BE/ME), external finance scaled by assets (EF/A), sales growth (GS). In the last three panels, we perform separate regressions within each size quintile and average coefficients across the five quintiles.

Panel A. Market model; ME, AGE, s

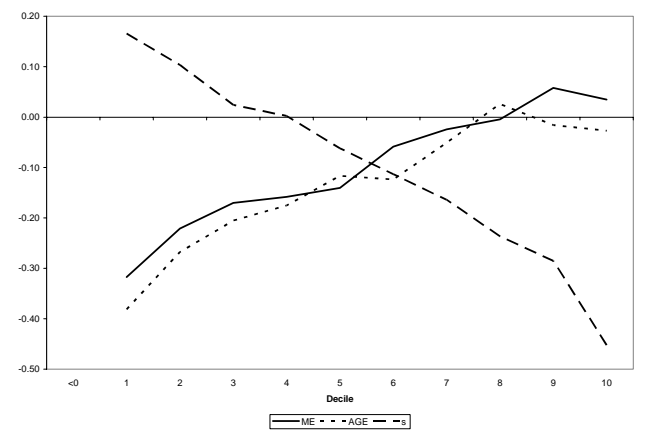

Panel B. Market model; D/BE, E/BE

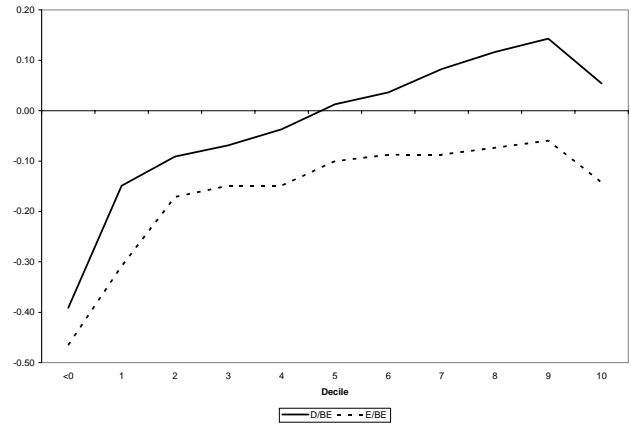

Panel C. Market model; BE/ME, EF/A, GS

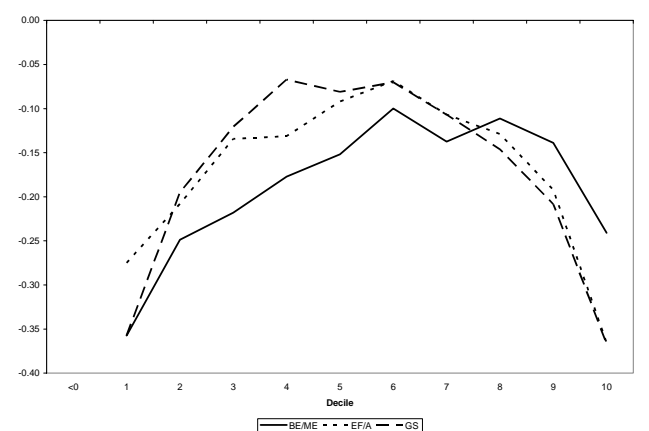

Panel D. Four factors; ME, AGE, s

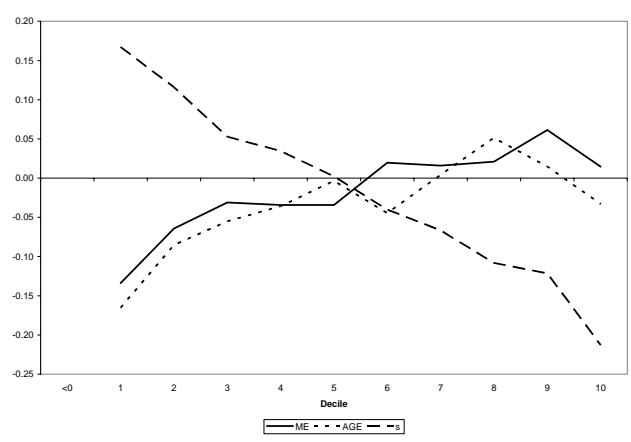

Panel E. Four factors; D/BE, E/BE

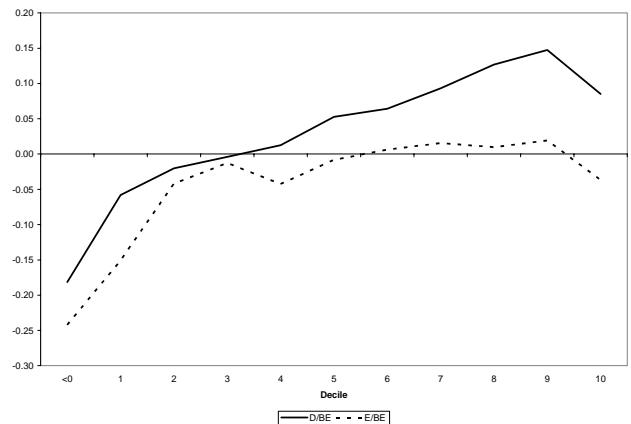

Panel F. Four factors; BE/ME, EF/A, GS

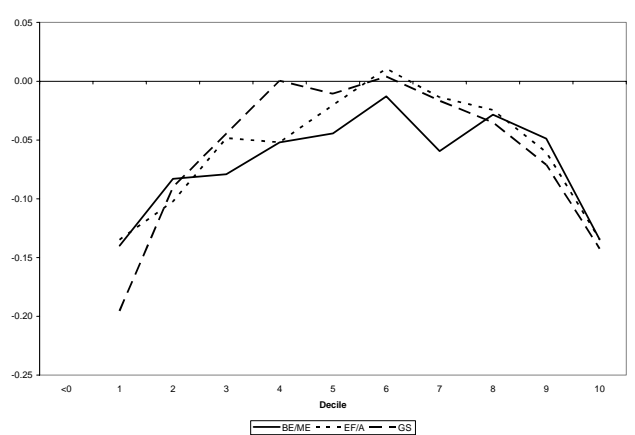

Panel G. Double sorts; AGE, s

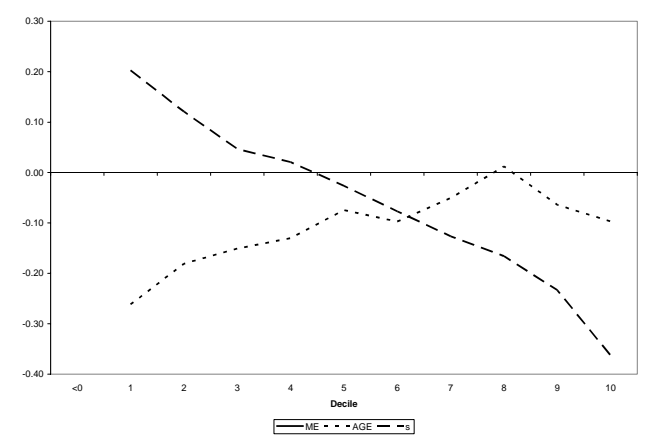

Panel H. Double sorts; D/BE, E/BE

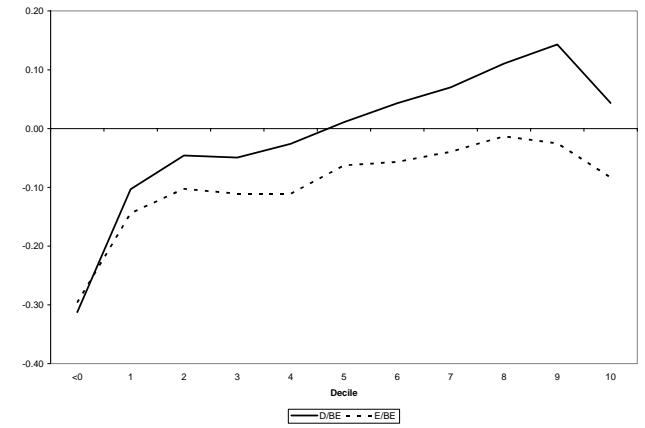

Panel I. Double sorts; BE/ME, EF/A, GS

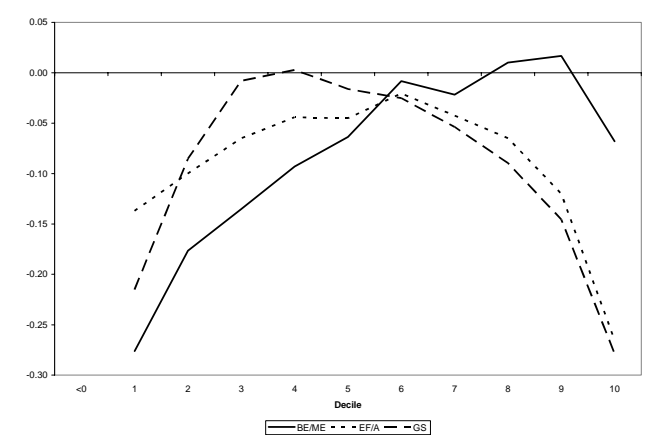


Figure 2. Predictable variation (Cochrane-Piazzesi) in bond returns and the cross-section of stock returns. We regress monthly excess portfolio returns on contemporaneous excess market returns and the predictable component of bond returns:

$$
r_{p t}-r_{f t}=a_{p}+\beta_{p}\left(r_{m t}-r_{f t}\right)+s_{p} S M B_{t}+h_{p} H M L_{t}+m_{p} U M D_{t}+t_{p}\left(r_{b t}-r_{f t}\right)^{*}+u_{p t}
$$

We report only $t_{p}$. The portfolios are formed equally-weighted within deciles on market capitalization (ME), age or years since CRSP listing (AGE), monthly volatility $(\sigma)$, dividends scaled by book equity (D/BE), profits scaled by book equity (E/BE), book-to-market ratio (BE/ME), external finance scaled by assets (EF/A), sales growth (GS). In the last three panels, we perform separate regressions within each size quintile and average coefficients across the five quintiles.

Panel A. Market model; ME, AGE, s

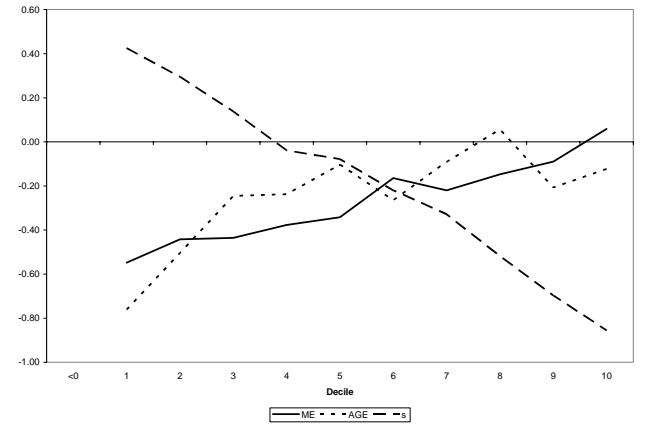

Panel B. Market model; D/BE, E/BE

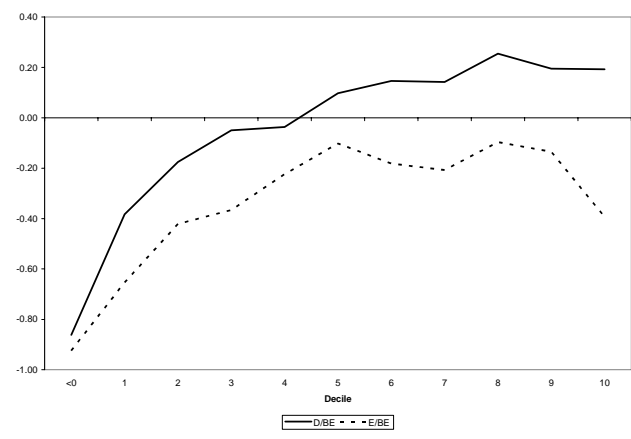

Panel C. Market model; BE/ME, EF/A, GS

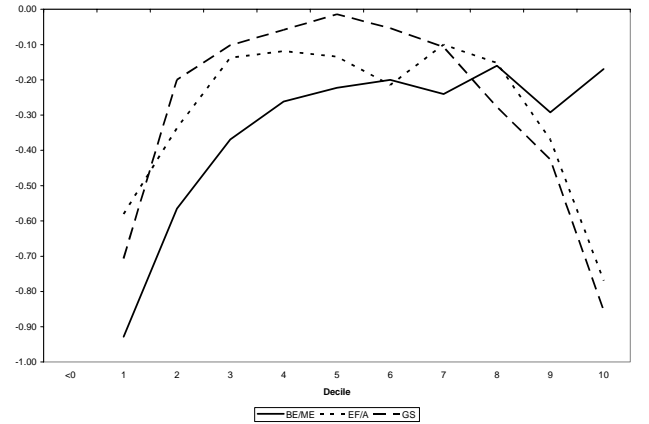

Panel D. Four factors; ME, AGE, s

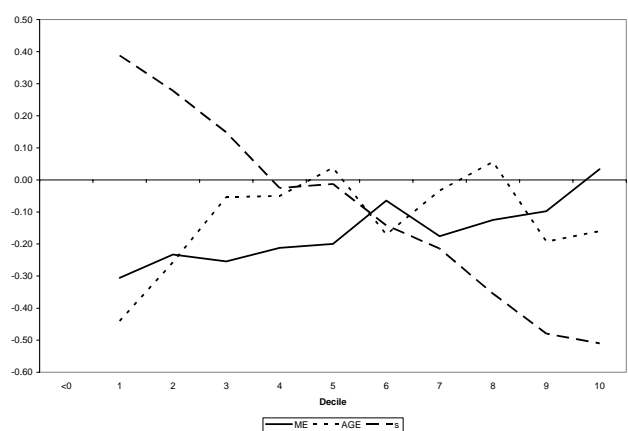

Panel E. Four factors; D/BE, E/BE

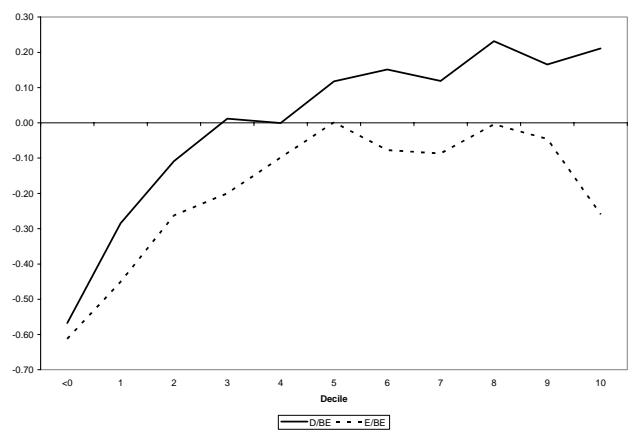

Panel F. Four factors; BE/ME, EF/A, GS

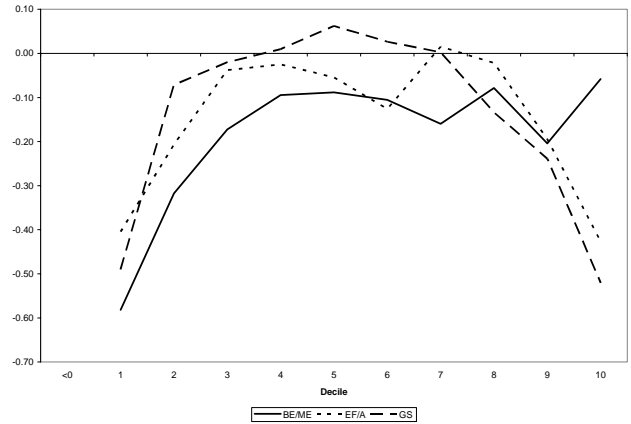

Panel G. Double sorts; AGE, s

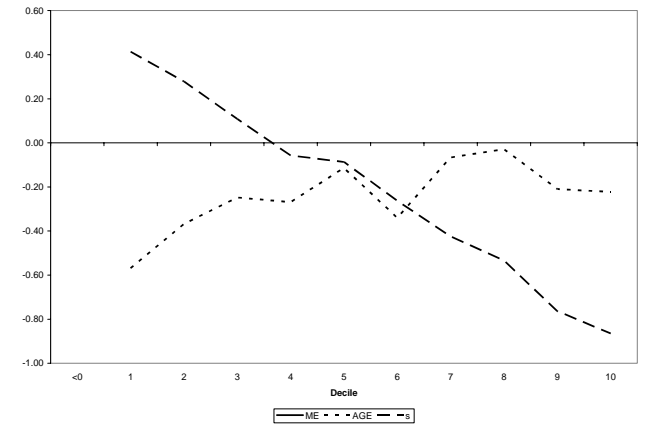

Panel H. Double sorts; D/BE, E/BE

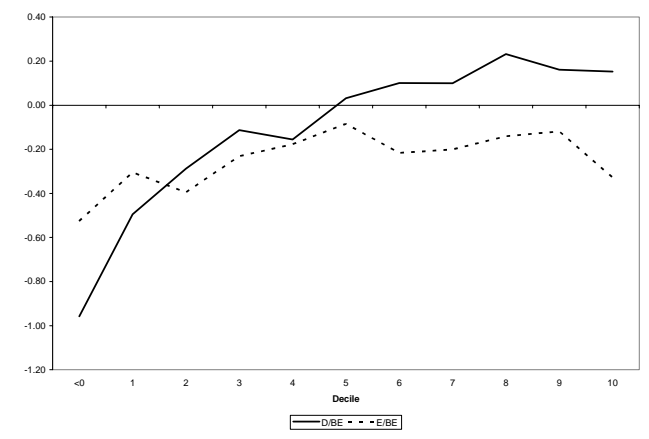

Panel I. Double sorts; BE/ME, EF/A, GS

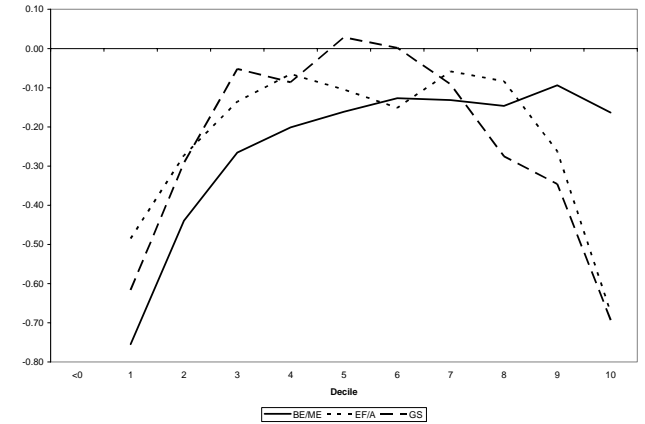


Figure 3. Predictable variation in bond returns and sentiment. Sentiment (from Figure 1; dashed line), the predictable component of bond returns from Campbell-Shiller (thin line), and the predictable component of bond returns from Cochrane-Piazzesi (thick line).

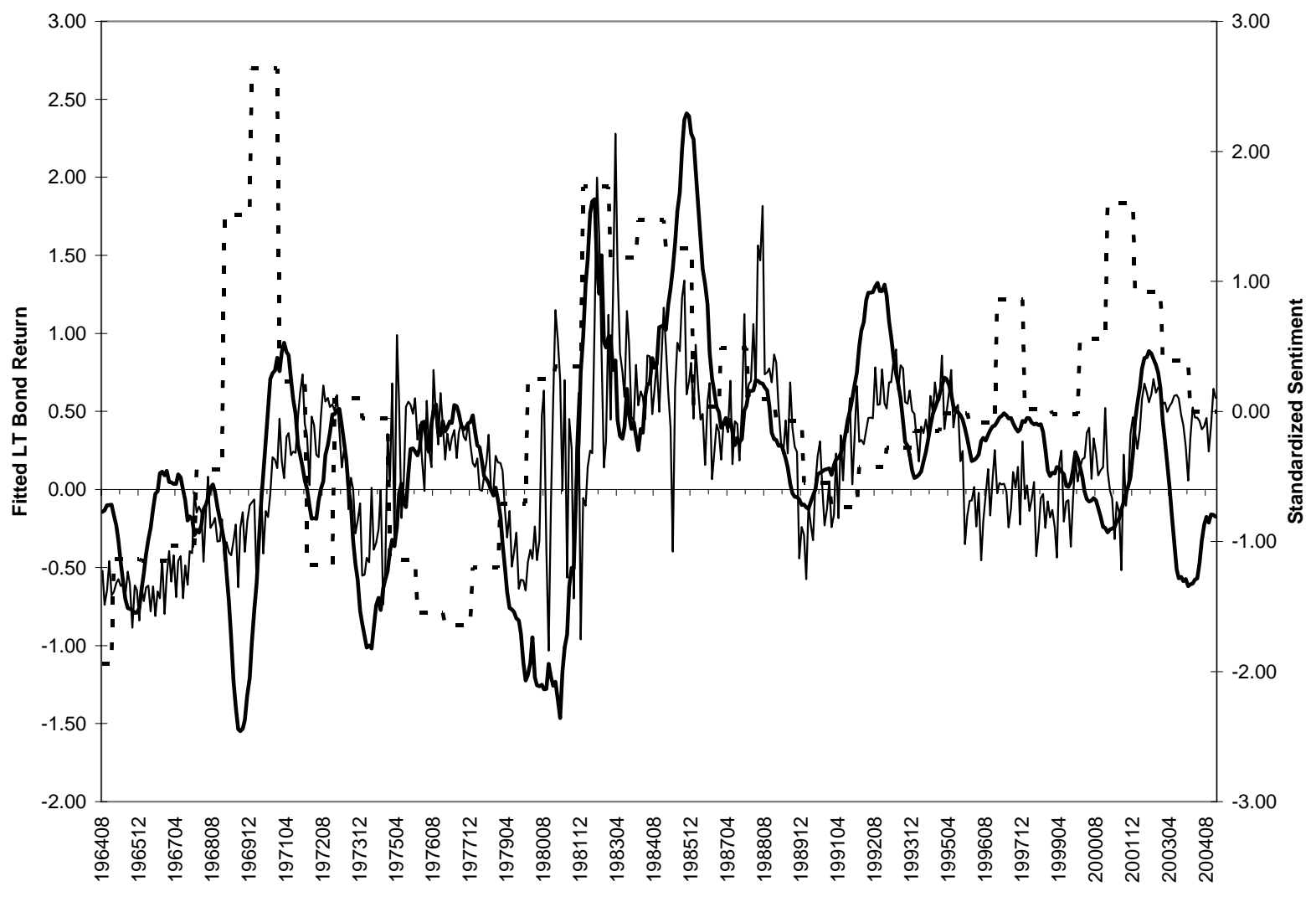

